\title{
Problematic Communication and Theories of Language in One Hundred Years of Solitude
}

\author{
Jonathon Ryan ${ }^{1}$
}

This essay explores ideas relating to the nature of language, literacy and communication as presented in the novel One Hundred Years of Solitude (1967), and expounds on how these ideas contribute to the novel's more central theme of personal isolation. The analysis suggests García Márquez engages with theories of language ranging from the Biblical account of Babel to more contemporary concerns such as the nature of reference and the influence of language and literacy on thought; of particular interest is the conflict that García Márquez identifies between the communicative and cognitive functions of language. In developing these themes, García Márquez effortlessly shifts from philosophical enquiry and reflection to humour and derision, but underlying each of these concerns is a profound appreciation of the interaction between a sense of isolation and the many forms of communicative breakdown. [Article copies available for a fee from The Transformative Studies Institute. E-mail address:_journal@transformativestudies.org Website: http://www.transformativestudies.org (C2013 by The Transformative Studies Institute. All rights reserved.]

KEYWORDS: García Márquez, One Hundred Years of Solitude, Miscommunication, Misidentification, Reference, Literacy, Theories of Language, Babel, Isolation.

\footnotetext{
${ }^{1}$ Jonathon Ryan teaches English at the Waikato Institute of Technology (Wintec), New Zealand, and has previously taught in Ireland and Mexico. He recently completed a Ph.D. in Applied Linguistics at the University of Waikato, with a thesis entitled 'Acts of reference and the miscommunication of referents by first and second language speakers of English'. His study used an Accessibility Theory framework to explore the triggers of communicative problems in cases where interlocutors misinterpreted the specific individuals that speakers were referring to. Some preliminary findings from his thesis were published in the TESOLANZ Journal, and he has recently published a chapter on the use of stimulated recall methodology to identify miscommunication. Address correspondence to: Jonathon Ryan; e-mail: jgr3@waikato.ac.nz.
} 